\title{
Pantropical Jumping Spiders in Florida ${ }^{1}$
}

G. B. Edwards, Jr. ${ }^{2}$

\section{Introduction}

Jumping spiders, or salticids, are so named because they have a highly coordinated jumping ability with which they capture prey and traverse from plant to plant. Their sense of sight is extraordinary for invertebrates; they can see in color (DeVoe 1975), and the large front eyes focus on objects (Land 1972). Many are marked with contrasting colors or bands, especially the males who display this ornamentation while dancing before females to win acceptance for mating. Jumping spiders as adults may be as small as $1 \mathrm{~mm}$ in length or as large as $23 \mathrm{~mm}$, but most are 5 to $10 \mathrm{~mm}$. All jumping spiders are harmless to humans, although the larger species can give a locally painful bite if roughly handled.

Two species of jumping spiders occurring in Florida. The gray wall jumper, Menemerus bivittatus (Dufour), and the pantropical jumper, Plexippus paykulli (Audouin), have been imported by man from the tropical Old World. Both are almost exclusively associated with man-made structures, usually buildings where they may be numerous around lights at night, catching the insects attracted to the lights. Both are medium- large jumping spiders, about 8 to
$12 \mathrm{~mm}$ in length. Adults and immatures of both species are present all year, although most mating and reproduction begin in the fall and continue until spring. Both are found from Florida to Texas and south to Paraguay. Menemerus bivittatus also occurs in California, and both species are widely distributed in the Old World tropics. The occurrence of dense populations of these two species around human habitations makes them of considerable beneficial importance in the control of flies, mosquitoes, and other human pests. At the same time, since they do not build webs to capture prey, they do not create the cobwebs which so often annoy many housewives.

\section{Gray Wall Jumper, Menemerus bivittatus (Dufour)}

\section{Abbreviated Synonymy}

Salticus bivittatus Dufour, 1831

Attus melanognathus Lucas, 1839

Marpissa melanognathus, Simon, 1883

Menemerus bivittatus, Simon, 1901; Barnes, 1958

1. This document is EENY-158 (originally published as DPI Entomology Circular 199), one of a series of Featured Creatures from the Entomology and Nematology Department, Florida Cooperative Extension Service, Institute of Food and Agricultural Sciences, University of Florida. Published: October 2000. Revised: September 2002. This document is also available on Featured Creatures Website at http://creatures.ifas.ufl.edu. Please visit the EDIS Website at http://edis.ifas.ufl.edu. Additional information on these organisms, including many color photographs, is available at the Entomology and Nematology Department website at http://entnemdept.ifas.ufl.edu/.

2. G. B. Edwards, Jr., Florida Department of Agriculture and Consumer Services, Division of Plant Industry, Gainesville, FL.

The Institute of Food and Agricultural Sciences is an equal opportunity/affirmative action employer authorized to provide research, educational information and other services only to individuals and institutions that function without regard to race, color, sex, age, handicap, or national origin. For information on obtaining other extension publications, contact your county Cooperative Extension Service office. Florida Cooperative Extension Service/Institute of Food and Agricultural Sciences/University of Florida/Christine Taylor Waddill, Dean. 


\section{Description}

This species is dorsoventrally flattened. The males are 8 to $9 \mathrm{~mm}$ in length, while females are 8 to10 $\mathrm{mm}$. In life, males appear to be longitudinally striped with alternating black and white, but in alcohol it is apparent that the dark abdominal stripes are reddish brown, and reddish-brown hairs also occur around the eyes. The carapace is mostly black with a white stripe on each side and one down the middle, the lateral stripes joining in front across the clypeus. A distinctive white inverted " $\mathrm{V}$ " mark occurs on the chellicerae. The female is gray dorsally, the carapace edged with a thin white stripe laterally and an orange clypeus; the semifoliar gray abdomen is edged with broad black stripes on each side which meet posteriorly. In alcohol, some reddish- brown hairs can be seen within the gray areas, especially on the abdomen. Immatures closely resemble the adult females, although sub-adult males may be distinguished by their swollen palpi. All free-living stages feed primarily on small Diptera which alight on buildings, although they are capable of capturing large crane flies twice their length, and larger, heavier muscoid flies. Females make a white eggsac in a crevice, somewhat flattened and about $1.5 \mathrm{~cm}$ in diameter, inside which they stay and guard 25 to 40 eggs which are contained inside a lenticular silken case about $6 \mathrm{~mm}$ in diameter. Spiderlings disperse about three weeks after the eggs are laid.

\section{Pantropical Jumper, Plexippus paykulli (Audouin)}

\section{Abbreviated Synonymy}

Attus paykullii Audouin, in Savigny, 1825

Plexippus ligo, C.L. Koch, 1846

Plexippus paykulli, Pavesi, 1883

Thotmes paykulli, F.O.P.-Cambridge, 1901

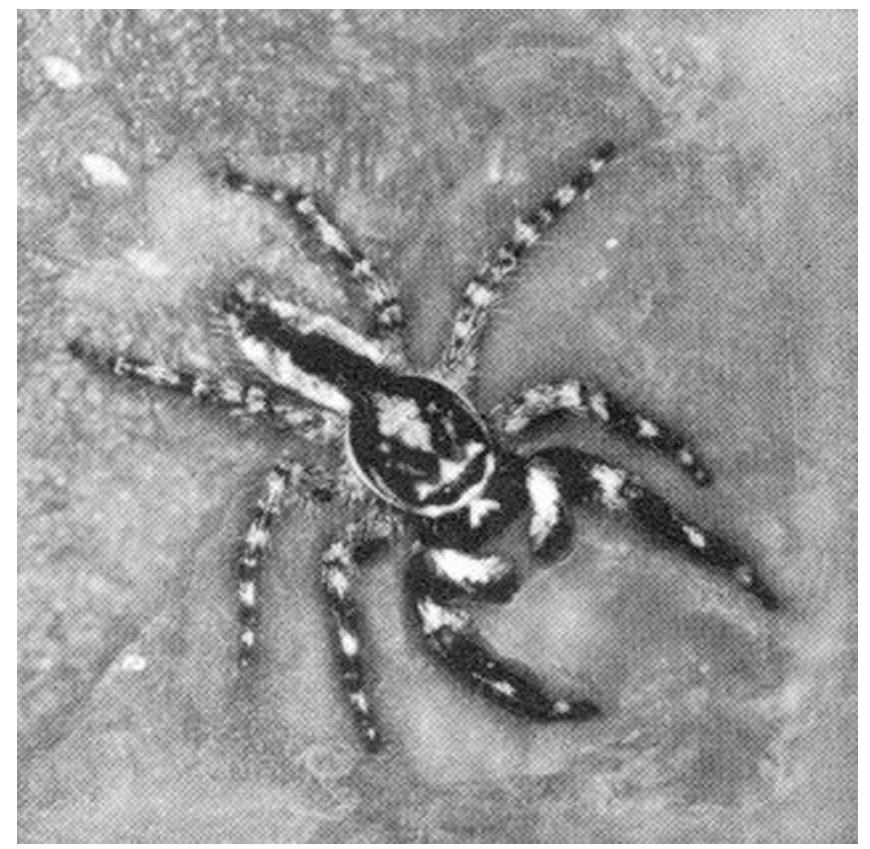

Figure 1. Male gray wall jumper, Menemerus bivittatus (Dufour). Credits: Division of Plant Industry

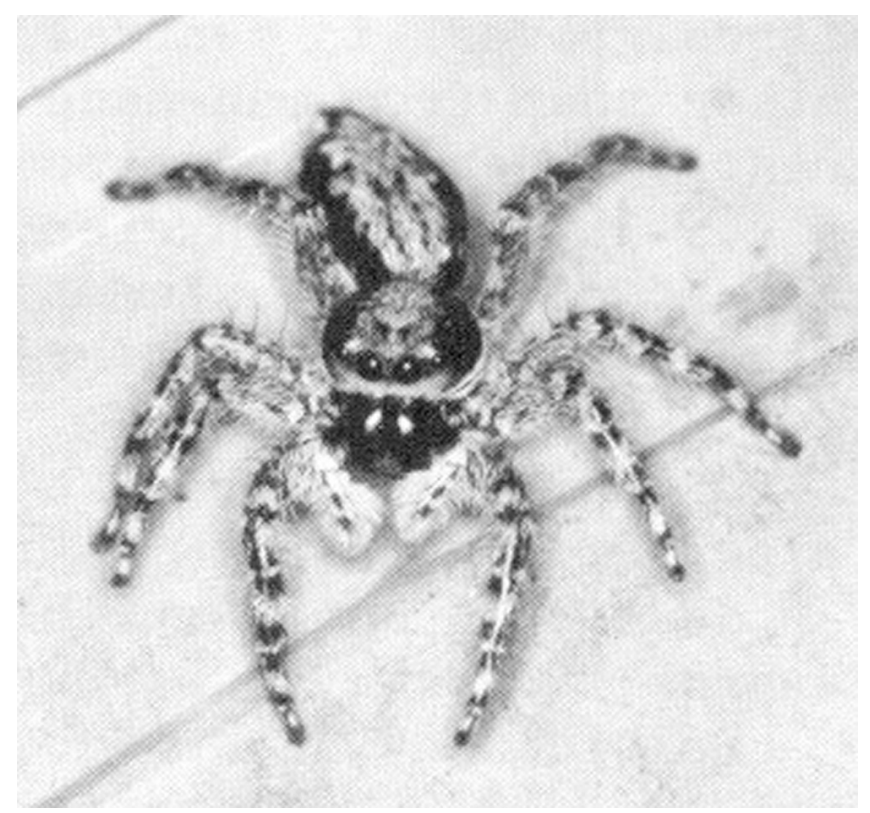

Figure 2. Female gray wall jumper, Menemerus bivittatus (Dufour). Credits: Division of Plant Industry

\section{Description}

This species is robust, with a high carapace. The males are 9 to11 $\mathrm{mm}$ in length, while the females are 9 to12 $\mathrm{mm}$. Males are distinctly black and white striped, but the order of the dark and light stripes on the abdomen is the reverse of that found in $M$. bivittatus, i.e., P. paykulli has a light central stripe bordered by dark stripes, whereas M. bivittatus has a dark central stripe bordered by light stripes. A pair of 
white spots occurs near the posterior tip of the abdomen. The male's carapace is marked similarly to that of $M$. bivittatus, with a central white stripe and a white stripe on each side, but these lateral stripes, instead of meeting in front on the clypeus, curve up, around, and between the anterior eyes. The central white stripe also continues between the anterior eyes, so that the face presents three white stripes on a black background. The female is brown: the carapace is darker, especially the ocular area, with a dull orange median stripe on the thoracic slope. The abdomen has two short black stripes on the posterior half, each containing two white spots, and a tan stripe down the middle with some darker chevrons within. As in most jumping spiders, the immatures resemble the adult female, although sub-adult males have more resemblance to adult males both in color pattern and in their swollen palpi. Adults and immatures feed on a wide variety of arthropod prey, including flies, moths, smaller spiders, and flying ants (Edwards et al. 1974). Muma (1975) observed P. paykulli in citrus groves in Central Florida -- the only recent report of this species from plants rather than from man-made structures. The eggsac is made by the female in a sheltered area, between or under boards, under eaves, or in suitably-sized crevices. The eggsac is 2.5 to 3.5 $\mathrm{cm}$ in diameter, and the female stays inside to guard a lenticular silken case about $9 \mathrm{~mm}$ in diameter containing 35 to 60 eggs. Spiderlings emerge and disperse between three and four weeks after the eggs are laid.

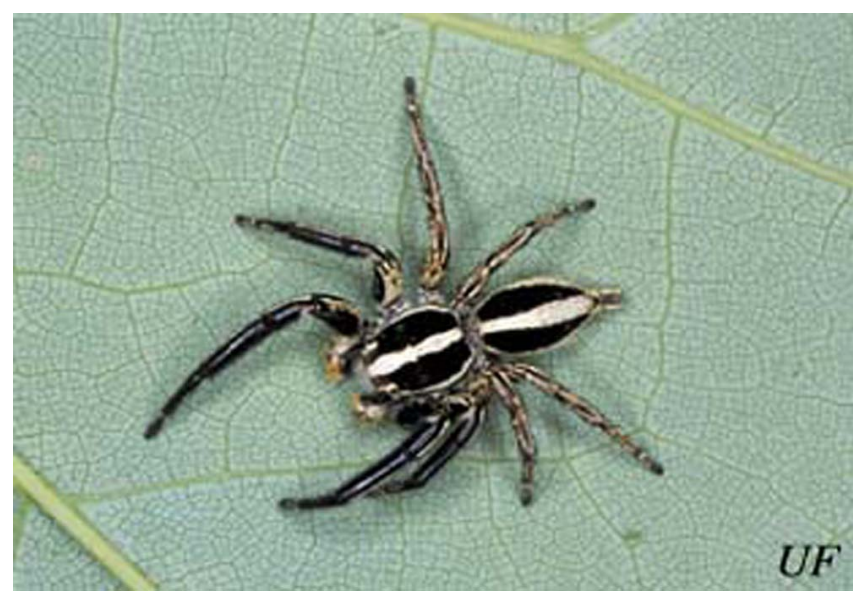

Figure 3. Male pantropical jumper, Plexippus paykulli (Audouin). Credits: University of Florida

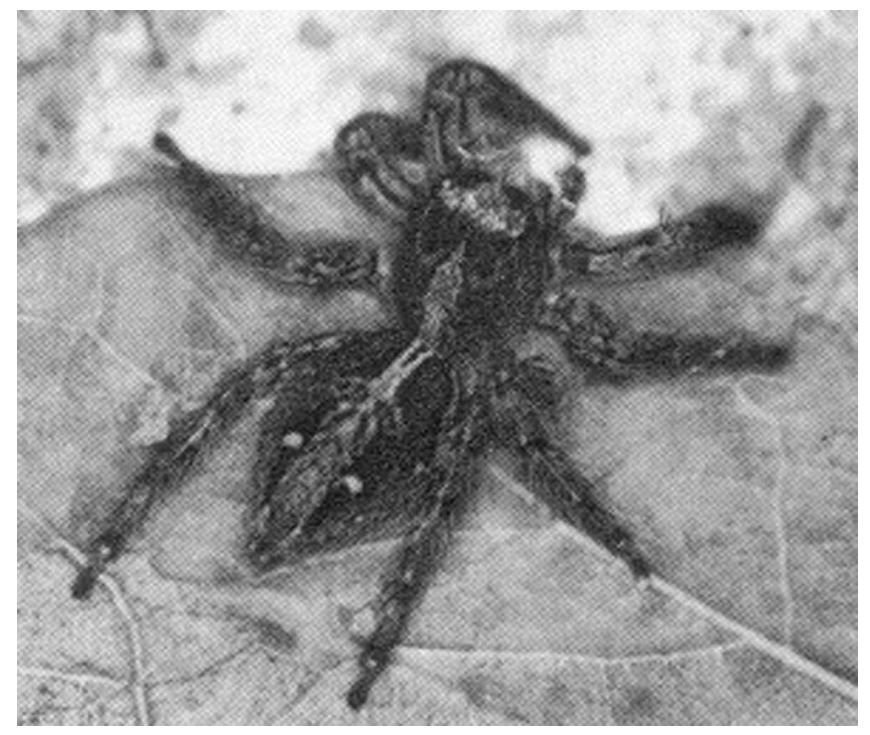

Figure 4. Female pantropical jumper, Plexippus paykulli (Audouin). Credits: Division of Plant Industry

\section{Selected References}

DeVoe, R.D. 1975. Ultraviolet and green receptors in principal eyes of jumping spiders. J. Gen. Physiol. 66: 193-208.

Edwards, G.B., J.F. Carroll, and W.H. Whitcomb. 1974. Stoidis aurata (Araneae: Salticidae), a spider predator of ants. Fla. Ent. 57: 337-346.

Edwards, G.B. (September 2000). Regal jumping spider, Phidippus regius C.L. Koch. UF/IFAS Featured Creatures. EENY-152. http://edis.ifas.ufl.edu/IN309 (3 October 2000).

Land, M. 1972. Mechanisms of orientation and pattern recognition by jumping spiders (Balticidae). Pages 231-247 in Information processing in the visual system of arthropods, R. Wehner, ed. Berlin, Springer-Verlag.

Muma, M.H. 1975. Spiders in Florida citrus groves. Fla. Ent. 58:83-90. 